\title{
Secondary Attack Rate of COVID-19 in Non- Household Contacts - A Systematic Review of Global Studies
}

\author{
Komal Shah', Smruti Prakash Mishra ${ }^{2}$, Einas lsmail Saeed ${ }^{3}$, Vishakha Bharti ${ }^{4}$, Bhavya Bhagat ${ }^{5}$, \\ Karan Gade $^{6}$, Mitali Panda ${ }^{7}$, Dileep Mavalankar ${ }^{8}$
}

${ }^{1}$ Assistant Professor, ${ }^{2,3,4,5,6,7} \mathrm{MPH}$ Student, ${ }^{8}$ Director, Indian Institute of Public Health Gandhinagar, Gujarat, India. DOI: https://doi.org/10.24321/0019.5138.202047

\section{I $\quad \mathbf{N} \quad \mathbf{F} \quad \mathbf{O}$}

\author{
Corresponding Author: \\ Komal Shah, ndian Institute of Public Health \\ Gandhinagar, Gujarat, India. \\ E-mail Id: \\ kshah@iiphg.org \\ Orcid Id: \\ https://orcid.org/0000-0003-0866-2386 \\ How to cite this article: \\ Shah K, Mishra SP, Saeed El, Bharti V, Bhagat B, \\ Gade K et al. Secondary Attack Rate of COVID-19 \\ in Non-Household Contacts - A Systematic Review \\ of Global Studies. J Commun Dis 2020; 52(4): \\ 97-107.
}

Date of Submission: 2020-11-19

Date of Acceptance: 2020-12-16

\section{$\begin{array}{lllllllllllllll}\mathbf{A} & \mathbf{B} & \mathbf{S} & \mathbf{T} & \mathbf{R} & \mathbf{A} & \mathbf{C} & \mathbf{T}\end{array}$}

Objective: Secondary Attack Rate (SAR) of COVID-19 varies across various populations. We aim to assess global articles reporting SAR in non-household contacts of COVID-19 patients through systematic review approach.

Methods: Four databases - MEDLINE, SCOPUS, Google Scholar and EMBASE were systematically searched for retrieval of articles reporting SAR of COVID-19 in various contacts. Initial search provided 436 articles, which through series of evaluation finally yielded 14 articles.

Result: Findings suggested that SAR in various contacts varies widely. Substantial number of studies (50\%) were from China; however, the two largest studies were from India. Irrespective of type of contacts, overall SAR ranged from $0.55-6 \%$. Highest risk was found from nonhousehold close (family, friends) contacts (2.2-22.31\%) followed by casual contact (travel, meal and health-care contacts). In spite of prolonged contact with the patients, SAR was lowest in health-care workers (0-7.3\%). Review highlighted that the included studies were suffering from limitations of missing data and continuously evolving operational guidelines.

Conclusion: The review showed that studies furnishing SAR data in non-household contacts are limited in number and exact mode of transmission is yet not clear. Six-percent of overall SAR indicates that though the disease is infectious in nature and proper precautions must be taken, not everybody that comes in contact with the index case is infected. However, with greater risk in non-household close contacts, it is important to identify vulnerable population and implement effective preventive strategies in them. Review also indicated serious data gaps in the published literature and stipulated need of more global studies.

Keywords: Covid-19, Non-Household Contact, Secondary Attack Rate 


\section{Introduction}

In continuation to our previous review that studied Secondary Attack Rate (SAR) in household contacts, ${ }^{1}$ current systematic review was planned to understand secondary transmission in non-household contacts of COVID-19 patients. The transmission trends of COVID-19 are still dynamic with multiple factors contributing to the SAR in different types of contacts. As stated by WHO understanding how, when and in what types of settings SARS-CoV-2 spreads between people is critical to develop effective public health and infection prevention measures to break chains of transmission. ${ }^{2}$ And unlike household contacts where few systematic reviews are already published, epidemiological features of SAR in non-household contacts are sporadically reported. With global lifting of lockdowns and gradual start of economic activities, it is important to study disease transmission in non-household contacts, identify its determinants and categorize population at risk. This will have direct implication on infection control and preventive strategy that needs to be opted during this new normal time.

Primarily COVID-19 transmission occurs through contact with respiratory droplets of infected symptomatic cases. ${ }^{3}$ Some of the early reports stated that close contact with a positive case within one meter and for prolonged period of time increases risk of secondary transmission in gym, travel, workplace and meal contacts. ${ }^{4,5}$ In medical settings airborne transmission is suspected due to variety of aerosol generating procedures. With this review, we aimed to extract information from globally published peer-reviewed studies regarding secondary transmission in non-household contacts of COVID-19 such as health care workers, travel contacts, family members and other close relatives (not sharing the same household), and meal contacts.

\section{Methods}

\section{Search Strategy}

The systematic review was conducted using the recommended method for systematic reviews and reporting based on Preferred Reporting Items for Systematic Reviews and Meta-Analysis (PRISMA). The "Cochrane Handbook for Systematic Reviews of Interventions" was followed for planning and conducting the review. ${ }^{6,7}$ Though studies reporting non-household SAR were selected for review, if mentioned, details of household SAR were also extracted from the studies.

\section{Search Strategies and Selection Criteria}

For identifying eligible articles, MEDLINE (through PubMed and CENTRAL) database was used. Search strategy was designed using keywords related to COVID-19 and secondary transmission. The key terms used were (("SARS-CoV-2" OR
“COVID- 19" OR “Coronavirus") AND ("secondary attack rate" OR "close contacts" OR "contact transmission")). After initial search in MEDLINE, Google scholar, EMBASE and SCOPUS was also explored to identify relevant articles along with the reference list of all the included articles. Articles published between December 2019 to $2^{\text {nd }}$ August 2020 were screened by two reviewers using title and abstracts evaluation. After that, screened articles were assessed using full text evaluation by four independent reviewers. Any discordance between the authors were settled by discussion and any difference of opinion arose was resolved through mutual consensus. Articles published in English language were included in the study. Other language articles were also included if summary in English was available.

Screening for duplicates removal and eligibility were conducted after initial search. Studies with missing data regarding SAR, population profile, number of included participants were excluded from the analysis. The articles meeting inclusion and exclusion criteria were finally selected for the systematic review and data regarding individual studies were extracted in excel. Thirty percent of the extracted data was validated by one of the reviewers before evidence synthesis. The flow chart of the screening and study selection is provided as PRISMA Figure 1.

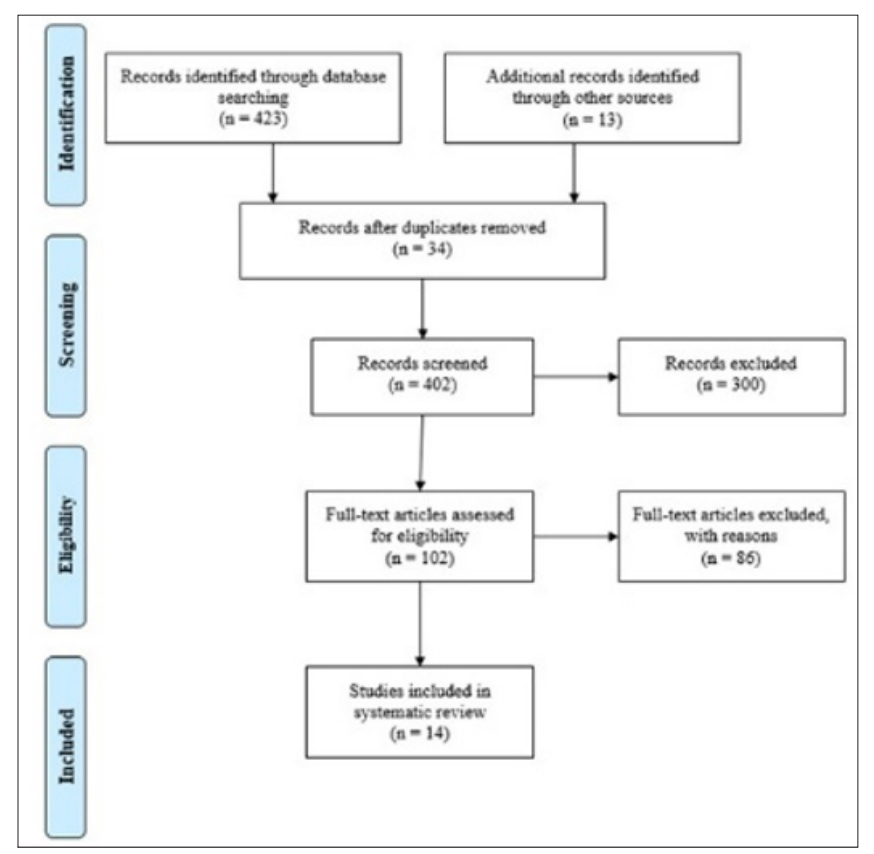

\section{Figure I.PRISMA diagram of included studies Data Extraction and Data Synthesis}

Data extraction was completed using a predefined tool and an excel matrix. The matrix was filled by six reviewers where same excel was used to avoid error. All six reviewers extracted the data and two of them verified it. Information regarding authors, country, study duration, time of patient enrolment, type of primary contact, number of primary and 
secondary cases, type of secondary cases, SAR in various types of contacts, key features and limitations of study were extracted from each article.

\section{Result}

After initial screening of 436 articles through series of evaluation between December 2019 and August 2020, 14 articles ${ }^{5,8-20}$ reporting SAR in all contacts of COVID-19 cases were included in the review. We did not include articles assessing SAR exclusively in household contacts as it was already reported by the authors during previous work and by others as well. The scope of the review was restricted to the contacts other than household that included casual contacts, workplace and healthcare workers contacts. The systematic review included 14 articles reporting SAR in various countries and population. ${ }^{8-23}$

Table I.Characteristics of the studies included in the systematic review

\begin{tabular}{|c|c|c|c|c|c|c|c|}
\hline $\begin{array}{l}\text { S. } \\
\text { No. }\end{array}$ & Author & Title & Country & $\begin{array}{c}\text { Number } \\
\text { of } \\
\text { contacts }\end{array}$ & $\begin{array}{l}\text { Number } \\
\text { of Primary } \\
\text { case }\end{array}$ & Type of contacts & $\begin{array}{c}\text { Study } \\
\text { duration }\end{array}$ \\
\hline 1. & $\begin{array}{l}\text { Abraham et } \\
\text { al., } 20208\end{array}$ & $\begin{array}{l}\text { Laboratory surveillance } \\
\text { for SARS COVID-2 in } \\
\text { India: Performance of } \\
\text { testing and descriptive } \\
\text { epidemiology of } \\
\text { detected COVID } 19\end{array}$ & India & 1021518 & 40184 & All contact & $\begin{array}{c}22^{\text {nd }} \\
\text { January- } \\
30^{\text {th }} \text { April } \\
2020\end{array}$ \\
\hline 2. & $\begin{array}{l}\text { Bi et al., } \\
20209\end{array}$ & $\begin{array}{c}\text { Epidemiology and } \\
\text { transmission of COVID-19 } \\
\text { in } 391 \text { cases and } 1286 \\
\text { of their close contacts } \\
\text { in Shenzhen, China: a } \\
\text { retrospective cohort } \\
\text { study }\end{array}$ & China & 1286 & 391 & Close contacts & $\begin{array}{l}\text { Jan } 14 \text { to } \\
\text { Feb } 12 \text {, } \\
2020\end{array}$ \\
\hline 3. & $\begin{array}{l}\text { Chen et al., } \\
202010\end{array}$ & $\begin{array}{l}\text { Epidemiological analysis } \\
\text { of infection among } \\
\text { close contacts of novel } \\
\text { coronavirus pneumonia } \\
\text { in Ningbo }\end{array}$ & China & 2147 & 157 & $\begin{array}{l}\text { Family } \\
\text { members, } \\
\text { friends and } \\
\text { medical staff }\end{array}$ & $\begin{array}{c}\text { January } \\
21 \text { to } \\
\text { March 6, } \\
2020\end{array}$ \\
\hline 4. & $\begin{array}{l}\text { Cheng et al., } \\
\text { (a) } 202011\end{array}$ & $\begin{array}{c}\text { Contact Tracing } \\
\text { Assessment of COVID-19 } \\
\text { Transmission Dynamics in } \\
\text { Taiwan and Risk at } \\
\text { Different Exposure } \\
\text { Periods Before and After } \\
\text { Symptom Onset }\end{array}$ & $\begin{array}{l}\text { Taiwan, } \\
\text { China }\end{array}$ & 2761 & 100 & $\begin{array}{l}\text { Contact with } \\
\text { household, } \\
\text { family, and } \\
\text { health care }\end{array}$ & $\begin{array}{c}\text { January } \\
15 \text { to } \\
\text { March } 18\end{array}$ \\
\hline 5. & $\begin{array}{l}\text { COVID-19 } \\
\text { National } \\
\text { Emergency } \\
\text { Response } \\
\text { Center3 }\end{array}$ & $\begin{array}{l}\text { Coronavirus Disease-19: } \\
\text { Summary of } 2,370 \\
\text { Contact Investigations of } \\
\text { the First } 30 \text { Cases in the } \\
\text { Republic of Korea }\end{array}$ & $\begin{array}{l}\text { Republic of } \\
\text { Korea }\end{array}$ & 2370 & 30 & All contacts & $\begin{array}{c}24^{\text {th }} \\
\text { January } \\
-10^{\text {th }} \\
\text { March }\end{array}$ \\
\hline 6. & $\begin{array}{l}\text { Draper et al., } \\
202012\end{array}$ & $\begin{array}{c}\text { The first } 2 \text { months of } \\
\text { coVID-19 contact tracing } \\
\text { in the Northern Territory } \\
\text { of Australia, March April } \\
2020\end{array}$ & Australia & 445 & 28 & \begin{tabular}{c|} 
Cruise ship \\
passengers, \\
household \\
contacts, aircraft \\
passengers, \\
healthcare \\
workers \\
\end{tabular} & $\begin{array}{l}1^{\text {st }} \text { March } \\
\text { and } 30^{\text {st }} \\
\text { April } 2020\end{array}$ \\
\hline
\end{tabular}




\begin{tabular}{|c|c|c|c|c|c|c|c|}
\hline 7. & Haung et al. ${ }^{13}$ & $\begin{array}{l}\text { Estimation of the } \\
\text { secondary attack rate of } \\
\text { COVID-19 using } \\
\text { proportional meta- } \\
\text { analysis of nationwide } \\
\text { contact tracing data in } \\
\text { Taiwan } \\
\end{array}$ & $\begin{array}{l}\text { Taiwan, } \\
\text { China }\end{array}$ & 3795 & 32 & $\begin{array}{l}\text { Close-contact } \\
\text { during meal, } \\
\text { household } \\
\text { or travel } \\
\text { environments }\end{array}$ & $\begin{array}{l}\text { April } 8^{\text {th }} \\
2020\end{array}$ \\
\hline 8. & $\begin{array}{l}\text { Kwok et al., } \\
202014\end{array}$ & $\begin{array}{c}\text { Epidemiological } \\
\text { characteristics of the first } \\
53 \text { laboratory-confirmed } \\
\text { cases of COVID-19 } \\
\text { epidemic in Hong Kong, } \\
13 \text { February } 2020\end{array}$ & Hong Kong & 206 & 24 & Close contacts & $13-F e b-20$ \\
\hline 9. & $\begin{array}{l}\text { Laxminarayan } \\
\text { et al., } 202015\end{array}$ & $\begin{array}{l}\text { Epidemiology and } \\
\text { transmission dynamics of } \\
\text { COVID-19 in two Indian } \\
\text { states }\end{array}$ & India & 64031 & 33584 & All contacts & $\begin{array}{l}\text { April } 1^{\text {st }} \text { to } \\
4^{\text {th }} \text { June }\end{array}$ \\
\hline 10. & $\begin{array}{l}\text { Luo et } \\
\text { al.,202016 }\end{array}$ & $\begin{array}{l}\text { Contact Settings and } \\
\text { Risk for Transmission in } \\
3410 \text { Close Contacts of } \\
\text { Patients With COVID-19 } \\
\text { in Guangzhou, China }\end{array}$ & $\begin{array}{l}\text { Guanghou, } \\
\text { China }\end{array}$ & 3410 & 391 & Close contacts & $\begin{array}{c}13 \\
\text { January } \\
\text { and } 6 \\
\text { March } \\
2020\end{array}$ \\
\hline 11. & $\begin{array}{l}\text { Macartney et } \\
\text { al., } 202017\end{array}$ & $\begin{array}{l}\text { Transmission of SARS- } \\
\text { CoV-2 in Australian } \\
\text { educational settings: a } \\
\text { prospective cohort study }\end{array}$ & Australia & 1448 & 27 & All contacts & $\begin{array}{c}\text { Jan } 13 \text { to } \\
\text { May } 1 \\
2020\end{array}$ \\
\hline 12. & Shen et al., ${ }^{18}$ & $\begin{array}{c}\text { A Cluster of Novel } \\
\text { Coronavirus Disease } \\
2019 \text { Infections } \\
\text { Indicating Person-to- } \\
\text { Person Transmission } \\
\text { Among Casual } \\
\text { Contacts from Social } \\
\text { Gatherings: An } \\
\text { Outbreak Case Contact } \\
\text { Investigation }\end{array}$ & USA & 539 & 7 & $\begin{array}{c}\text { Close and casual } \\
\text { contacts }\end{array}$ & $\begin{array}{l}\text { Mid- } \\
\text { January } \\
\text { to early } \\
\text { February } \\
2020\end{array}$ \\
\hline 13. & $\begin{array}{l}\text { Wang et al., } \\
202019\end{array}$ & $\begin{array}{l}\text { Basic epidemiological } \\
\text { parameter values } \\
\text { from data of real } \\
\text { world in mega-cities: } \\
\text { the characteristics of } \\
\text { COVID-19 in Beijing, } \\
\text { China }\end{array}$ & China & 2902 & 602 & Close contacts & $\begin{array}{c}\text { Jan } 1^{\text {st }} \text { to } \\
\text { Apr } 3^{\text {rd }} \\
2020\end{array}$ \\
\hline 14. & $\begin{array}{l}\text { Wee et al., } \\
202020\end{array}$ & $\begin{array}{l}\text { Containing COVID-19 } \\
\text { outside the isolation } \\
\text { ward: The impact of an } \\
\text { infection control bundle } \\
\text { on environmental } \\
\text { contamination and } \\
\text { transmission in a } \\
\text { cohorted general ward }\end{array}$ & Singapore & 45 & 28 & $\begin{array}{l}\text { Staff and patient } \\
\text { close contacts }\end{array}$ & $\begin{array}{c}\text { February } \\
7 \text { to May } \\
7,2020\end{array}$ \\
\hline
\end{tabular}


Table 2.Secondary attack rate in different contacts of COVID-I9 primary case

\begin{tabular}{|c|c|c|c|c|c|c|c|}
\hline \multicolumn{2}{|c|}{ All contact } & \multicolumn{2}{|c|}{ Non-household close contacts } & \multicolumn{2}{|c|}{ Casual contacts } & \multicolumn{2}{|c|}{ Health care workers } \\
\hline Author & SAR (\%) & Author & SAR (\%) & Author & SAR (\%) & Author & SAR (\%) \\
\hline $\begin{array}{l}\text { Abraham et } \\
\text { al., } 2020\end{array}$ & $\begin{array}{c}\text { Unadjusted } \\
\text { SAR -6\%; } \\
\text { Adjusted } \\
-3.9 \%\end{array}$ & $\begin{array}{l}\text { Bi et } \\
\text { al., } \\
2020\end{array}$ & $\begin{array}{c}\text { Meal contact }-8.6 \% \\
(6 \cdot 8-10 \cdot 9)\end{array}$ & $\begin{array}{l}\text { Bi et al., } \\
2020\end{array}$ & $\begin{array}{l}\text { Travel contact - } \\
5.7 \%(3 \cdot 6-8 \cdot 8)\end{array}$ & $\begin{array}{l}\text { Chen et } \\
\text { al., } 2020\end{array}$ & $0 \%$ \\
\hline $\begin{array}{c}\text { Chen et al., } \\
2020\end{array}$ & $6.15 \%$ & $\begin{array}{l}\text { Chen } \\
\text { et al., } \\
2020\end{array}$ & $\begin{array}{c}\text { Friends/pilgrims } \\
(22.31 \%) ; \text { Non- } \\
\text { household family } \\
\text { members (18.01\%); } \\
\text { Relatives }(4.73 \%)\end{array}$ & $\begin{array}{l}\text { Draper et } \\
\text { al., } 2020\end{array}$ & $\begin{array}{c}\text { Travel contact } \\
-4.3 \%(95 \% \mathrm{Cl} \\
0.5-14.8 \%)\end{array}$ & $\begin{array}{l}\text { Chen et } \\
\text { al., } 2020\end{array}$ & $\begin{array}{c}0.9 \%(95 \\
\mathrm{Cl}, 0.4 \%- \\
1.9 \%)\end{array}$ \\
\hline $\begin{array}{c}\text { Chen et al., } \\
2020\end{array}$ & $\begin{array}{c}0.7 \%(95 \% \\
\mathrm{Cl}, 0.4 \%- \\
1.0 \%)\end{array}$ & $\begin{array}{l}\text { Chen } \\
\text { et al., } \\
2020\end{array}$ & $\begin{array}{c}\text { Non-household } \\
\text { family contact - } 5.3 \% \\
(95 \% \mathrm{Cl}, 2.1 \%-12.8 \%)\end{array}$ & $\begin{array}{l}\text { Chen et } \\
\text { al., } 2020\end{array}$ & $\begin{array}{c}\text { Multiple setting: } \\
0.1 \%(95 \% \mathrm{Cl}-0 \%- \\
0.3 \%)\end{array}$ & $\begin{array}{l}\text { Draper et } \\
\text { al., } 2020\end{array}$ & $0 \%$ \\
\hline $\begin{array}{l}\text { COVID-19 } \\
\text { National } \\
\text { Emergency } \\
\text { Response } \\
\text { Center }\end{array}$ & $\begin{array}{c}0.55 \%(95 \% \\
\mathrm{Cl} 0.31- \\
0.96)\end{array}$ & $\begin{array}{l}\text { Kwok } \\
\text { et al., } \\
2020\end{array}$ & $\begin{array}{c}\text { Close contact - } \\
11.7 \%(95 \% \mathrm{Cl}: 7.61 \\
\text { to } 16.8)\end{array}$ & $\begin{array}{l}\text { Laxmi- } \\
\text { narayan } \\
\text { et al., } \\
2020\end{array}$ & $\begin{array}{c}\text { Community - } 2.6 \% \\
\text { (1.6-3.9\%); } \\
\text { Travel contact } \\
-80.8 \% \text { (48.6- } \\
\text { 98.5\%); Other } \\
\text { multiple settings - } \\
2.1 \%(0.4-4.4 \%)\end{array}$ & $\begin{array}{l}\text { Laxshmi- } \\
\text { narayan } \\
\text { et al., } \\
2020\end{array}$ & $\begin{array}{c}1.0 \%(0.0- \\
5.4 \%)\end{array}$ \\
\hline Haung et al & $\begin{array}{c}0.88 \%(95 \% \\
\mathrm{Cl}: 0.42 \%- \\
1.69 \%)\end{array}$ & $\begin{array}{l}\text { Shen } \\
\text { et al., } \\
2020\end{array}$ & $0.29 \%$ & $\begin{array}{l}\text { Luo et } \\
\text { al.,2020 }\end{array}$ & $\begin{array}{c}\text { Travel contact }-0.1 \\
(0.0-0.4) ; \text { Multiple } \\
\text { setting }-13.0 \\
(0.0-26.8)\end{array}$ & $\begin{array}{l}\text { Luo et al., } \\
2020\end{array}$ & $\begin{array}{c}1.0 \\
(0.3-1.8)\end{array}$ \\
\hline $\begin{array}{l}\text { Laxmi- } \\
\text { narayan et } \\
\text { al., } 2020\end{array}$ & $\begin{array}{c}6.0 \%(95 \% \\
\text { Cl: } 5.0- \\
7.3 \%)\end{array}$ & $\begin{array}{l}\text { Wee } \\
\text { et al., } \\
2020\end{array}$ & Close contact - $2.2 \%$ & $\begin{array}{l}\text { Shen et } \\
\text { al., } 2020\end{array}$ & $0.60 \%$ & $\begin{array}{l}\text { Wang et } \\
\text { al., } 2020\end{array}$ & $7.30 \%$ \\
\hline $\begin{array}{l}\text { Luo et al., } \\
2020\end{array}$ & $\begin{array}{c}3.72 \%(95 \% \\
\mathrm{Cl}, 3.1 \%- \\
4.4 \%)\end{array}$ & & & $\begin{array}{l}\text { Wang et } \\
\text { al., } 2020\end{array}$ & $\begin{array}{c}\text { Other social } \\
\text { contacts - } 4.6 \% ; \\
\text { Non-health care } \\
\text { workers - } 4.2 \%\end{array}$ & $\begin{array}{l}\text { Wee et } \\
\text { al., } 2020\end{array}$ & $0 \%$ \\
\hline $\begin{array}{l}\text { Macartney } \\
\text { et al., } 2020\end{array}$ & $0.012 \%$ & - & - & - & - & - & - \\
\hline $\begin{array}{l}\text { Wang et al., } \\
2020\end{array}$ & $\begin{array}{l}4.6 \%(95 \% \\
\mathrm{Cl}: 4.0-5.3)\end{array}$ & - & - & - & - & - & - \\
\hline
\end{tabular}

\section{Characteristic details of the Included Studies}

As presented in Table 1, substantial number of studies have reported SAR from China $(n=7,50 \%)$ - the country from where the disease was originated. Two large studies assessing transmission trends in 10,21,518 and 64,031 contacts were published from India. Abraham et al8 represented National statistics of SAR across all States of India whereas Laxshinarayan et al., ${ }^{15}$ studied disease transmission dynamics from two south Indian States. Studies were completed between the months of January to early June 2020 , with varied sample size of the primary cases
(28 - 40184 laboratory confirmed cases). The studies have documented SAR in non-household family contacts, relatives, health care workers and close travel contacts.

\section{Secondary Attack Rate in Contacts of COVID-19}

SAR in different types of contacts are presented in Table 2. It was observed that irrespective of type of contacts, overall SAR ranged from $0.55 \%$ to $6 \%$. Highest risk was found non-household close contacts (2.2\%-22.31\%) followed by casual contact (travel, meal and health care contacts). In spite of prolonged contact with the patients, SAR was lowest in health care workers (0-7.3\%). This could be 
due to preventive measures implemented at healthcare settings. Travelling, meal and other casual contacts have showed varied degree of SAR (0.1\%-22.31\%). Only one study published by Laxshinarayan et al., ${ }^{15}$ showed very high SAR - 80.8\% in travel contact. The authors used the data generated through public health surveillance activities undertaken by the Health and Family Welfare Department of the Government of Tamil Nadu and the Department of Health, Medical and Family Welfare Department of the Government of Andhra Pradesh. However, detailed methodology regarding contact tracing and testing for calculating SAR in travel contacts could not be retrieved from the article. Hence, we excluded these findings from overall synthesis.

Table 3.Key findings and limitations of the included studies

\begin{tabular}{|c|c|c|c|}
\hline $\begin{array}{l}\text { S. } \\
\text { No. }\end{array}$ & Author & Key findings & Limitations \\
\hline 1. & $\begin{array}{c}\text { Abraham et al., } \\
2020\end{array}$ & $\begin{array}{l}\text { 1) The secondary attack data was corrected for missing data } \\
\text { using sensitivity analysis and it reduced from } 6 \% \text { to } 3.9 \% \text {. } \\
\text { The corrected SAR was highest in Chandigarh (11.5\%) and } \\
\text { Maharashtra ( } 10.6 \%) \text {. } \\
\text { 2) SAR in different state ranged from } 0-11.5 \% \text {. } \\
\text { 3) SAR analysis was different between groups with known } \\
\text { versus unknown contacts. This might have contributed in } \\
\text { variation in SAR. }\end{array}$ & $\begin{array}{l}\text { 1) For some variables such } \\
\text { as patient category or date } \\
\text { of symptom onset, the } \\
\text { proportion of entries with } \\
\text { missing data was high. } \\
\text { 2) Overall individual and } \\
\text { system level variations need } \\
\text { to be considered during } \\
\text { analysis }\end{array}$ \\
\hline 2. & Bi et al., 2020 & $\begin{array}{l}\text { 1) Household contacts and those travelling with a case were at } \\
\text { higher risk of infection (odds ratio } 6 \cdot 27 \text { [ } 95 \% \mathrm{Cl} 1 \cdot 49-26 \cdot 33] \text { for } \\
\text { household contacts and } 7 \cdot 06 \text { [1.43-34.91] for those travelling } \\
\text { with a case) than other close contacts. } \\
\text { 2) Children were as likely to be infected as adults (infection rate } \\
7 \cdot 4 \% \text { in children }<10 \text { years vs population average of } 6 \cdot 6 \%) \text {. } \\
\text { 3) Reproductive number ( } \mathrm{R} \text { ) was } 0 \cdot 4(95 \% \mathrm{Cl} 0 \cdot 3-0 \cdot 5) \text {, with a } \\
\text { mean serial interval of } 6 \cdot 3 \text { days }(95 \% \mathrm{Cl} 5 \cdot 2-7 \cdot 6) \text {. }\end{array}$ & $\begin{array}{l}\text { 1) Variation due to } \\
\text { continuously evolving } \\
\text { protocols and multiple level } \\
\text { data collection. } \\
\text { 2) Implementation of } \\
\text { contact tracing guideline } \\
\text { hugely depended on } \\
\text { local testing capacity and } \\
\text { surveillance resources. }\end{array}$ \\
\hline 3. & $\begin{array}{c}\text { Chen et al., } \\
2020\end{array}$ & $\begin{array}{l}\text { 1) Difference between infection rates in close contacts } \\
\text { of confirmed cases and asymptomatic infections was not } \\
\text { statistically significant. } \\
\text { 2) Among close contacts of different relationships, friends/ } \\
\text { pilgrims, family members, and relatives have higher infection } \\
\text { rates. } \\
\text { 3) No infection occurred in close contacts of medical staff. } \\
\text { 4) Living with the case ( } 13.26 \%) \text {, taking the same means of } \\
\text { transportation ( } 11.91 \%) \text {, and having dinner and entertainment } \\
\text { (7.18\%) were all-high-risk factors for infection. Cross-infection in } \\
\text { the hospital diagnosis and treatment environment was } 1.94 \% \text {. }\end{array}$ & \\
\hline 4. & $\begin{array}{l}\text { Cheng et al., } \\
\text { (a)., } 2020\end{array}$ & $\begin{array}{l}\text { 1) The attack rate was higher among the contacts whose } \\
\text { exposure to index cases started within } 5 \text { days of symptom onset } \\
\text { ( } 1.0 \% \text { [ } 95 \% \mathrm{Cl}, 0.6 \%-1.6 \%] \text { ) compared with those who were } \\
\text { exposed later ( } 95 \% \mathrm{Cl}, 0 \%-0.4 \%) \text {. } \\
\text { 2) The contacts with exclusive pre-symptomatic exposures were } \\
\text { also at risk (attack rate, } 0.7 \% \text { [ } 95 \% \mathrm{Cl}, 0.2 \%-2.4 \%]) \text {. } \\
\text { 3) The attack rate was higher among household }(4.6 \% \text { [ } 95 \% \mathrm{Cl} \text {, } \\
2.3 \%-9.3 \%] \text { ) and non-household ( } 5.3 \% \text { [ } 95 \% \mathrm{Cl}, 2.1 \%-12.8 \%]) \\
\text { family contacts than that in health care or other settings. } \\
\text { 4) The attack rates were higher among those aged } 40 \text { to } 59 \\
\text { years ( } 1.1 \% \text { [ } 95 \% \mathrm{Cl}, 0.6 \%-2.1 \%]) \text { and those aged } 60 \text { years and } \\
\text { older ( } 0.9 \% \text { [ } 95 \% \mathrm{Cl}, 0.3 \%-2.6 \%]) \text {. }\end{array}$ & $\begin{array}{l}\text { 1) No complete } \\
\text { examination of contacts } \\
\text { before the symptom onset } \\
\text { of the index cases. } \\
\text { 2) Effect of household and } \\
\text { non-household contact in } \\
\text { early phases could not be } \\
\text { separated out. }\end{array}$ \\
\hline
\end{tabular}




\begin{tabular}{|c|c|c|c|}
\hline 5. & \begin{tabular}{|c} 
COVID-19 \\
National \\
Emergency \\
Response \\
Center, \\
Epidemiology \\
and Case \\
Management \\
Team, Korea \\
Centers for \\
Disease Control \\
and Prevention \\
\end{tabular} & $\begin{array}{l}\text { 1) Risk of symptomatic cases from transmission to contacts was } \\
\text { low. } \\
\text { 2) The transmission of COVID-19 was significant among } \\
\text { household contacts. } \\
\text { 3) Contact tracing relies on other concurrent aspects of } \\
\text { the COVID-19 containment strategies such as investigating, } \\
\text { classifying, tracking, and managing contacts by identifying the } \\
\text { patient's route. }\end{array}$ & $\begin{array}{l}\text { 1) With increase in number } \\
\text { of cases the control strategy } \\
\text { has changed. Its impact has } \\
\text { not been evaluated. } \\
\text { 2) Secondly, potential } \\
\text { risk factors such as } \\
\text { the characteristics of a } \\
\text { household and other } \\
\text { transmission routes were } \\
\text { not assessed. }\end{array}$ \\
\hline 6. & $\begin{array}{l}\text { Draper et al., } \\
\quad 2020\end{array}$ & $\begin{array}{l}\text { Transmission of COVID-19 to household contacts and close } \\
\text { contacts from a cruise ship with known on-board transmission } \\
\text { is detected. }\end{array}$ & $\begin{array}{l}\text { In flight transmission was } \\
\text { not evaluated }\end{array}$ \\
\hline 7. & $\begin{array}{l}\text { Haung et al., } \\
2020\end{array}$ & $\begin{array}{l}\text { 1) Low SAR in close contact environment. } \\
\text { 2) The low SAR of COVID-19 in Taiwan may result from the } \\
\text { effective strategic approaches, including inspecting imported } \\
\text { passengers with symptoms, monitoring quarantined individuals } \\
\text { by government-issued cell phones, the efficient distribution } \\
\text { of facial masks to people in need, and discouraging mass } \\
\text { gathering. }\end{array}$ & \\
\hline 8. & $\begin{array}{l}\text { Kwok et al., } \\
2020\end{array}$ & $\begin{array}{l}\text { 1) Pre-symptomatic transmission and containment } \\
\text { delay, which in turn fosters symptomatic transmission, occurred } \\
\text { during the early phase of the COVID-19 epidemic in Hong Kong. } \\
\text { 2) With a considerable containment delay and short serial } \\
\text { interval, contact-tracing effectiveness may not be optimised to } \\
\text { halt the transmission with rapid generations replacement. } \\
\text { 3) Transmission risk of social interaction and pivotal role of } \\
\text { physical distancing in suppressing the epidemic was highlighted } \\
\text { by the study. }\end{array}$ & $\begin{array}{l}\text { 1) Recall bias might have } \\
\text { affected data accuracy. } \\
\text { 2) Unclear data reporting. } \\
\text { 3) Availability of insufficient } \\
\text { information. } \\
\text { 4) Limited understanding } \\
\text { on clinical characteristics of } \\
\text { COVID-19. }\end{array}$ \\
\hline 9. & $\begin{array}{l}\text { Laxmi-narayan } \\
\text { et al., } 2020\end{array}$ & $\begin{array}{l}\text { 1) Reproduction numbers ranged from } ~ 2-3 \text { during in March. } \\
\text { Reduction was observed after lockdown and social distancing. } \\
\text { 2) Substantial variation in individuals' likelihood of transmitting: } \\
\text { no secondary infections were linked to } 83 \% \text { of cases whose } \\
\text { contacts were traced. } \\
\text { 3) No difference in infection risk among contacts of infected } \\
\text { children and adults. } \\
\text { 4) Equivalent transmission risk across ages. } \\
\text { 5) } 50 \% \text { of fatalities occurring within the first } 5 \text { days of testing - } \\
\text { substantially shorter time to mortality. }\end{array}$ & $\begin{array}{l}\text { 1) Gaps in availability of } \\
\text { contact tracing data. } \\
\text { 2) Lack of data on timing } \\
\text { of exposure and symptoms } \\
\text { onset in relation to testing } \\
\text { dates. } \\
\text { 3) Varied sensitivity } \\
\text { of RT-PCR might have } \\
\text { misclassified some cases. }\end{array}$ \\
\hline 10. & Luo et al., 2020 & $\begin{array}{l}\text { 1) Compared with the household setting, the secondary attack } \\
\text { rate was lower for exposures in healthcare settings ( } 1.0 \% \text {; odds } \\
\text { ratio [OR], } 0.09 \text { [Cl, } 0.04 \text { to } 0.20] \text { ) and on public transportation } \\
(0.1 \% \text {; } O R, 0.01 \text { [Cl, } 0.00 \text { to } 0.08] \text { ). } \\
\text { 2) The secondary attack rate increased with the severity of } \\
\text { index cases. } \\
\text { 3) Index cases with expectoration were associated with higher } \\
\text { risk for secondary infection ( } 13.6 \% \text { vs. } 3.0 \% \text { for index cases } \\
\text { without expectoration; OR, } 4.81 \text { [Cl, } 3.35 \text { to } 6.93] \text { ). }\end{array}$ & $\begin{array}{l}\text { 1) Potential recall bias } \\
\text { regarding symptom onset } \\
\text { among patients with } \\
\text { COVID-19. } \\
\text { 2) Severity of index cases } \\
\text { were not assessed at the } \\
\text { time of exposure to contact. }\end{array}$ \\
\hline
\end{tabular}




\begin{tabular}{|c|c|c|c|}
\hline 11. & $\begin{array}{l}\text { Macartney et } \\
\text { al., } 2020\end{array}$ & $\begin{array}{l}\text { 1) Low incidence of attendance of children and staff members } \\
\text { with COVID-19 at educational facilities. } \\
\text { 2) The use of enhanced surveillance and serological testing of } \\
\text { close contacts within the educational setting contributed in } \\
\text { preventive strategies. }\end{array}$ & $\begin{array}{l}\text { 1) Changing operational } \\
\text { definitions might have } \\
\text { contributed in the under/ } \\
\text { over interpretation. } \\
\text { 2) Inability to assess } \\
\text { adherence to or the } \\
\text { effect on transmission } \\
\text { of recommendations } \\
\text { regarding hygiene or } \\
\text { physical distancing in } \\
\text { educational settings, } \\
\text { and these progressively } \\
\text { increased in magnitude } \\
\text { over the study period. }\end{array}$ \\
\hline 12. & Shen et al. & $\begin{array}{l}\text { 1) There was strong evidence of COVID-19 transmission to } \\
\text { contacts outside of the immediate family members. } \\
\text { 2) COVID-19 is possibly transmitted more via a droplet } \\
\text { mechanism rather than airborne as indicated by large difference } \\
\text { between the SAR in casual and close contacts. } \\
\text { 3) COVID-19 prevalence continues to increase, the attack rate } \\
\text { from casual contact between individuals with COVID-19 and } \\
\text { susceptible individuals is critical to understanding further } \\
\text { spread of the epidemic. } \\
\text { 4) COVID-19 can be transmitted through casual contact with a } \\
\text { source patient at social events even in areas of fewer cases. }\end{array}$ & $\begin{array}{l}\text { Compromised sensitivity } \\
\text { of the diagnostic tests } \\
\text { might have contributed in } \\
\text { misinterpretation of some } \\
\text { cases }\end{array}$ \\
\hline 13. & $\begin{array}{l}\text { Wang et al., } \\
2020\end{array}$ & $\begin{array}{l}\text { 1) The household secondary attack rate of COVID-19 was } \\
\text { slightly higher than SARS. } \\
\text { 2) Due to the atypical or unspecific presence of mild infection } \\
\text { or asymptomatic infection, the family members had been } \\
\text { fully exposed to cases before they were confirmed, and this } \\
\text { increased the risk of infection among household close contacts. } \\
\text { 3) SAR of HCWs was relative higher than that of } \\
\text { non-HCWs'. }\end{array}$ & $\begin{array}{l}\text { 1) Lost to follow up of some } \\
\text { close contacts. } \\
\text { 2) Detailed information } \\
\text { on exposure history as } \\
\text { frequency, intensity, and } \\
\text { duration for all cases was } \\
\text { not available. } \\
\text { 3) The relationship between } \\
\text { index cases and their } \\
\text { quarantined close contact } \\
\text { was not well recorded. }\end{array}$ \\
\hline 14. & $\begin{array}{l}\text { Wee et al., } \\
2020\end{array}$ & $\begin{array}{l}\text { An infection control bundle } \\
\text { comprising infrastructural enhancements, improved PPE } \\
\text { and social-distancing mitigated the risk of environmental } \\
\text { contamination and transmission in a cohorted general ward } \\
\text { setting. }\end{array}$ & $\begin{array}{l}\text { 1) Only symptomatic cases } \\
\text { were included. As the } \\
\text { diagnostic yield of PCR } \\
\text { testing for SARS-CoV-2 is } \\
\text { likely dependent on the } \\
\text { quality of sampling. } \\
\text { 2) The viability of the virus } \\
\text { found from environmental } \\
\text { samples could not be } \\
\text { ascertained. } \\
\text { 3) Inability to perform air } \\
\text { sampling for index cases, } \\
\text { as upon confirmation of } \\
\text { covID-19. }\end{array}$ \\
\hline
\end{tabular}




\section{Key Features and Limitations of the Included Studies}

Detailed information regarding trends and characteristics of transmission in various types of contacts were extracted from each study and is presented in Table 3. The summary of the findings can be listed as follows:

- SAR varies widely among various studies and various settings

- Friends, family, and relatives of index cases were having highest risk for SAR

- Travel contacts and other casual contacts such as community contacts were at relatively low risk with reported range of $0.1 \%-4.6 \%$. Only one study showed very high (80.8\%)15 secondary transmission rate from travel contact

- All seven studies have clearly indicated very low SAR in health care workers

- SAR of health care workers (HCWs) was relative higher than that of non-HCWs'

- Contacts aged 40-59 and more than 60 years are more susceptible to secondary infection

- Containment policies, quarantining of positive and susceptible cases, wearing masks and contact tracing have significant impact on reduction in secondary infection.

- Frequency and duration of contact with primary case has close association with SAR. Exposure to primary case within 5 days of symptom onset has resulted in higher SAR as compared to exposure after 5 days

- Symptomatic or primary case with symptoms infected more contacts than cases without symptoms

- Mass gatherings and social events triggered more secondary infections even in case of fewer primary patients

- Attack rate from casual contact between individuals with COVID-19 and susceptible individuals is still unclear and needs to be explored further

Majority of the authors identified limitation in the study and have explicitly listed them down while interpreting the findings (Table 3). The commonly presented limitations were as follows:

- Almost all the studies have accepted the issue of data gaps and few of the investigators undertook sensitivity analysis to adjust the missing data bias

- With continuously evolving guidelines of testing, isolation and quarantining, there were several operational changes in studies that might have influenced analysis and actual statistics of SAR

- Testing of all the contacts was a main challenge faced by majority of the countries as contact tracing and surveillance hugely depend on countries, provinces and cities preparedness in terms of testing capacity and surveillance capacity

- A significant proportion of contacts might be missed during pre-symptomatic phases and hence identification of source of infection (e.g. household, non-household) was also a challenge in them

- Recall bias was also an important possible confounder of SAR assessment as cases may have missed/forgotten to list all contacts

- Varied sensitivity of the diagnostic tools (70\% sensitivity of RTPCR) might have underestimated secondary cases

\section{Discussion}

The global review summarises findings from 14 different studies and reports that overall SAR of COVID-19 varies widely with multifactorial transmission trend. To the best of our knowledge, this is the first review reporting SAR in non-household contacts that included findings from close contacts such as family, friends and relatives as well as casual contacts such as travel, community and health care contacts.

Review yielded three important pieces of information regarding secondary transmission of COVID-19 in various contacts: 1) Overall SAR is relatively low, with some selected contacts being more vulnerable to secondary infection due to variety of reasons. Various studies when assessed SAR irrespective of contact type found that overall SAR ranges from $0.55-6.15 \%$. This indicates that though the disease seems to be highly infectious in nature, majority of the secondary cases are contributed by particular type of contacts only. This also emphasises the need to relook at overall containment and quarantining strategies. 2) Non-household family members, relatives and friends of index cases are at highest risk of secondary infection due to similar reasons what we have observed in household contacts during our previous review. This might be due to lack of protective gears such as mask and greater contact time with the index cases. ${ }^{9}$ These contacts did not share same household with the patients but to due to their relation with the case it is expected that they might have frequent interactions with patients. This could be during both symptomatic and asymptomatic state of the index case. It reinforces the need to introduce specific contact tracing, screening and testing strategies for these contacts. Though this group had lower risk of secondary infection as compared to household contacts (reported SAR range: $5-50 \%$ ), the review indicates that it contributes to the significant number of secondary cases. Hence after household contacts, these contacts are at higher risk of SAR. 3) Casual contacts are at lowest risk of SAR. Three studies reported transmission risk while travelling with a positive contact and it was found be ranging from $0.1 \%$ $5.7 \%$. Firstly, due to global lockdowns very limited number of studies have reported this. However, the lower rate 
could be explained by adequate protective and preventive measures implemented by various Governments. Wide use of mask, personal protective equipment, strict restriction on unnecessary travel and screening for any symptoms might have contributed for this lower secondary transmission in the travel contacts. Only one study identified transportation as high-risk exposure settings. Authors found that individuals who travelled in close $(<1 \mathrm{~m})$ proximity to an index case in a shared conveyance were at the greatest risk of infection: this exposure was associated with 30.61 (23.03-40.75) fold higher risk than community exposure.

One of the important finding of the review is the low SAR in health care contacts in spite of multiple contacts with the patients. Several explanations can be proposed for this: 1) It is known that a positive case is most infectious 2 days prior to and 3 days after the symptom onset and during this phase the viral shedding is highest. As per operational guidelines of various countries mild and moderate cases during this phase are generally advised home quarantine. Hence, healthcare workers do not have much exposure to patients at this time. It is the severe cases at much later stage of infection are being treated at hospital set ups. 2) It might be also due to appropriate infection control measures, usage of personal protective equipment and following of disease prevention guidelines. 3) Due to familiarity with the treatment strategies and better awareness regarding signs and symptoms there might be some early intervention in this groups of contacts and hence lower reporting as well. However, these results should be evaluated with cautions as there are emerging grey literature reporting increased infection in health care workers and even documenting fatal outcomes in many.

Apart from these key observations, the included studies have mentioned some of the important limitations. The disease is continuously evolving and so is the scientific fraternity's knowledge regarding the disease. This has affected operational guidelines of respective country for contact tracing and testing on which SAR data was hugely dependant. Similarly, enormous amount of resources are needed to track and test all the contacts. Hence there was substantial gap in terms of contacts that has been tested. Majority of the studies have accepted the assumption that "not tested is not positive". Only few studies have conducted sensitivity analysis for adjustment of this assumption. In conclusion, the current report is one of the first systematic review providing important clue in understanding the secondary transmission trends in various contacts, although it might be just a tip of an iceberg with lot of information still needing to be explored.

\section{Conclusion}

The review suggests that studies reporting SAR in nonhousehold contacts are limited in number and exact mode of transmission is yet not clear. It showed that the disease is infectious in nature and hence adequate precautions must be taken to prevent secondary transmission. However, it is important to note that not everybody that comes in contact with the index case is infected. It is recommended to identify vulnerable population and implement effective preventive strategies in them. However, SAR studies have some inherent bias that may have led to underestimation of the transmission in contacts.

Conflict of Interest: None

\section{References}

1. Shah K, Saxena D, Mavalankar D. Secondary Attack Rate of COVID-19 in household contacts: Systematic review. QJM 2020 Jul 29.

2. World Health Organization. Transmission of SARS-CoV-2: implications for infection prevention precautions: scientific brief, 09 July 2020. WHO; 2020.

3. Jayaweera $M$, Perera $H$, Gunawardana $B$, Manatunge J. Transmission of COVID-19 virus by droplets and aerosols: A critical review on the unresolved dichotomy. Environ Res 2020: 109819.

4. Qureshi Z, Jones N, Temple R, Larwood JP, Greenhalgh $\mathrm{T}$, Bourouiba L. What is the evidence to support the 2-metre social distancing rule to reduce COVID-19 transmission. Accessed on: https://www. cebm. net/ covid-19/what-is-the-evidenceto-support-the-2-metresocial-distancing-rule-to-reduce-covid-19-transmission. 2020.

5. COVID-19 National Emergency Response Center, Epidemiology and Case Management Team, Korea Centers for Disease Control and Prevention. Coronavirus Disease-19: Summary of 2,370 Contact Investigations of the First 30 Cases in the Republic of Korea. Osong Public Health Res Perspect 2020; 11(2): 81-84.

6. Mathie RT, Lloyd SM, Legg LA, Clausen J, Moss S, Davidson JR et al. Randomised placebo-controlled trials of individualised homeopathic treatment: systematic review and meta-analysis. Syst Rev 2014; 3(1): 142.

7. Higgins JP. Cochrane handbook for systematic reviews of interventions. Version 5.1. 0 [updated July 2019]. The Cochrane Collaboration. www. cochrane-handbook. org. 2011.

8. Abraham P, Aggarwal N, Babu GR et al. Laboratory surveillance for SARS-CoV-2 in India: Performance of testing and descriptive epidemiology of detected COVID-19, January 22- April 30, 2020. Indian J Med Res 2020; 151(5): 424-37.

9. Bi Q, Wu Y, Mei S, Ye C, Zou X, Zhang Z et al. Epidemiology and transmission of COVID-19 in 391 cases and 1286 of their close contacts in Shenzhen, China: a retrospective cohort study. Lancet Infect Dis 2020; 20(8): 911-19.

10. Chen Y, Wang A, Yi B, Ding K, Wang H, Wang J et al. 
Epidemiological characteristics of infection in COVID-19 close contacts in Ningbo city. PubMed [Internet]. 2020 [cited 6 November 2020]; 41(5): 667-671.

11. Cheng $\mathrm{H}$, Jian S, Liu D, Ng T, Huang W, Lin H. Contact Tracing Assessment of COVID-19 Transmission Dynamics in Taiwan and Risk at Different Exposure Periods Before and After Symptom Onset. JAMA Intern Med 2020; 180(9): 1156.

12. Draper A, Dempsey K, Boyd R, Childs E, Black H, Francis L et al. The first 2 months of COVID-19 contact tracing in the Northern Territory of Australia, March-April 2020. Commun Dis Intell 2020; 44.

13. Huang Y, Tu Y, Lai P. Estimation of the secondary attack rate of COVID-19 using proportional meta-analysis of nationwide contact tracing data in Taiwan. J Microbiol Immunol Infect 2020.

14. Kwok K, Wong V, Wei W, Wong S, Tang J. Epidemiological characteristics of the first 53 laboratory-confirmed cases of COVID-19 epidemic in Hong Kong, 13 February 2020. Euro Surveill 2020; 25(16).

15. Laxminarayan R, Wahl B, Dudala S, Gopal K, B C, Neelima $S$ et al. Epidemiology and transmission dynamics of COVID-19 in two Indian states [Internet]. Science. 2020 [cited 7 November 2020]. Available from: https:// science.sciencemag.org/content/early/2020/09/29/ science.abd7672.full.

16. Luo L, Liu D, Liao X, Wu X, Jing Q, Zheng J, Liu F, Yang S, $\mathrm{Bi} \mathrm{H}, \mathrm{Li}$ Z, Liu J. Contact settings and risk for transmission in 3410 close contacts of patients with COVID-19 in Guangzhou, China: a prospective cohort study. Ann Intern Med 2020.

17. Macartney K, Quinn HE, Pillsbury AJ, Koirala A, Deng L, Winkler N, Katelaris AL, O'Sullivan MV, Dalton C, Wood N, Brogan D. Transmission of SARS-CoV-2 in Australian educational settings: a prospective cohort study. Lancet Child Adolesc Health 2020; 4(11): 807-16.

18. Shen Y, Xu W, Li C, Handel A, Martinez L, Ling F et al. A Cluster of Novel Coronavirus Disease 2019 Infections Indicating Person-to-Person Transmission Among Casual Contacts From Social Gatherings: An Outbreak Case-Contact Investigation. InOpen Forum Infect Dis 2020; 7(6): ofaa231.

19. Wang X, Pan Y, Zhang D, Chen L, Jia L, Li X et al. Basic epidemiological parameter values from data of realworld in mega-cities: the characteristics of COVID-19 in Beijing, China.

20. Wee LE, Sim XY, Conceicao EP, Aung MK, Tan KY, Ko KK, et al. Containing COVID-19 outside the isolation ward: the impact of an infection control bundle on environmental contamination and transmission in a cohorted general ward. Am J Infect Control 2020; 48(9): 1056-61. 